\title{
Morphological Concept in Evaluating Riverbank Slum Settlement Programs in Kotalama Malang
}

\author{
Nuryantiningsih Pusporini*, Windhasari Retno Palupi, Dewi Septanti, Sarah Cahyadini, \\ Happy Ratna Santosa
}

\begin{abstract}
Department of Architecture, Faculty of Civil, Planning and Geo Engineering, Institut Teknologi Sepuluh Nopember, 60111, Surabaya, Indonesia
\end{abstract}

Received February 2, 2021; Revised March 29, 2021; Accepted April 18, 2021

\section{Cite This Paper in the following Citation Styles}

(a): [1] Nuryantiningsih Pusporini, Windhasari Retno Palupi, Dewi Septanti, Sarah Cahyadini, Happy Ratna Santosa, "Morphological Concept in Evaluating Riverbank Slum Settlement Programs in Kotalama Malang," Civil Engineering and Architecture, Vol. 9, No. 3, pp. 634-645, 2021. DOI: 10.13189/cea.2021.090307.

(b): Nuryantiningsih Pusporini, Windhasari Retno Palupi, Dewi Septanti, Sarah Cahyadini, Happy Ratna Santosa (2021). Morphological Concept in Evaluating Riverbank Slum Settlement Programs in Kotalama Malang. Civil Engineering and Architecture, 9(3), 634-645. DOI: 10.13189/cea.2021.090307.

Copyright $\odot 2021$ by authors, all rights reserved. Authors agree that this article remains permanently open access under the terms of the Creative Commons Attribution License 4.0 International License

\begin{abstract}
Slum settlements in Kotalama are characterized by some building irregularities and poor sanitation and waste management. Flood and landslide are also two potential threats. The government provides inspection road and embankment construction plans as part of watershed management programs. This study aims to evaluate the plans using qualitative and quantitative methods. Data is obtained from planning and scientific documents, field observation, and interviews. The morphology of settlements was analyzed using space syntax analysis to determine the integration and connectivity of space. The riverbanks morphology is analyzed to determine the placement of the inspection road and embankment. The results show that the inspection road can increase citizens' connectivity to the centre of the area and enable them to access the waste transportation system. The use of depthmapX as a tool for evaluating connectivity is a practical way to apply data source and application. The Indonesian government can use it for a more diverse planning evaluation. Meanwhile, the riverbank's morphological analysis shows that using ecohydrological engineering, the construction of inspection road and embankment could reduce damage to the river's ecology and function. Also, the government can use the concept of designing more sustainable river embankments.
\end{abstract}

Keywords Riverbank Settlements, Slums, Space and Riverbank Morphology

\section{Introduction}

Growth and economic development in urban areas are one of the causes of urbanization. The increase in urban population increases housing demand, leading to an increase in housing prices and rent. This situation put some low-income people into a difficulty to build or rent proper housing. These people then commonly stay at non-residential areas such as riversides or railways, which lead to the emergence of slum settlements in Indonesia. Several factors causing the growth of slum settlements include high urbanization, limited land availability in cities, socio-economic and socio-cultural conditions[1].

The typology of housing and slum settlements is divided into five: housing and slum settlements on riverbanks, on the edge of the water, on lowlands, on the hills, and disaster-prone areas[2]. Slum settlements in Kotalama Malang are primarily located in the riverbanks of the Amprong River. The slum settlements in Brantas riverbank in Malang is relatively close to the settlers' workplace (radius $<2 \mathrm{~km}$ ) with a house size of $10-20 \mathrm{~m}^{2}$. Most of the residents who are traders do not hold the legality of land ownership except the legality of building permits for some[3].

The Amprong River, which passes the centre of Malang City, is close to Kebalen Market and Central Market. It 
becomes one of the densely populated settlements in the city. Based on the 2015 decree of the Mayor of Malang, Kotalama is categorized as a light slum area. Based on Kotaku data in 2018, the main problems of slum settlements in Kotalama are the density and irregularity of buildings, waste management that does not comply with technical requirements, and a high risk of landslides.

The Malang City Government, through the City without Slum (Kotaku) program and deliberation on development plans (Musyawarah Rencana Pembangunan/Musrenbang), seeks to reorganize the riverbank slum areas in Kotalama through the construction of inspection roads and embankments. The inspection road construction plan aims to increase accessibility and as a waste transportation route. The embankment construction plan is to prevent landslides and has been equipped with a technical planning document.

Before the programs are executed in the construction process, it is necessary to evaluate their effectiveness in achieving the objectives. They will be evaluated using the concept of spatial morphology and riverbank morphology. The morphology concept will test the accessibility of inspection roads and the placement of road plans and embankments that can maintain riverbanks' ecological function.

\section{Materials and Methods}

This research uses quantitative and qualitative methods. Quantitative methods are applied in space syntax analysis by using building map data and road networks. Also, in riverbanks morphological analysis, by using river cross-section measurement data obtained from the Detail Engineering Design (DED) Document of Kotalama Slum Improvement Plan in 2020. Qualitative methods are applied in providing an overview of the research location and socio-culture condition obtained from the results of field observations and interviews with the residents. Qualitative data is also obtained from related books, journals, and documents.

\subsection{Morphology of Space Concept}

Analysis of settlement forms, using syntax spaces, can describe spatial arrangements and concepts related to the type and amount of space[4]. The analytical model sees settlements as a bi-polar system arranged between a primary cell or a building (house, etc.) and a carrier (the world outside the settlement). Space syntax can be used for observation and spatial arrangement to produce spatial integration, both visually and optimally[5]. Measuring the local and global characteristics of space graphs makes it possible to describe the configuration of accessibility and visibility[6].

The use of space syntax analysis provides direction to determine the integration and connectivity of space from the area of research location. Furthermore, the analysis can show which spaces have high integration and connectivity so that it can be used to see whether the inspection road plan is suitable to be constructed.

Syntax space analysis was carried out using depthmapX[7]: visual and spatial network analysis software. depthmapX generates a map of spatial elements and relate them via relationships (intervisibility, intersection, or proximity) and then perform graph analysis of the resulting network. The two steps that will be taken are:

\section{- Visual Analysis}

It is used to assess the visual accessibility by generating point isovist (polygons representing the visually accessible area of a location) and isovist paths that show how the view changes as it moves through space. The data used for visual analysis is the building's shapefile map and the research area's boundaries. The interpretation is through spatial integration, which sees zones and spaces that are more dominant integrated with other spaces. Spatial integration considers the distance between spaces where a close space will result in a more integrated space. The integration indication will be shown as a colour change.

\section{- Axial and Segment Analysis}

They were used to derive axial maps from a layout, i.e. a network of reduced straight lines of open space in an environment. The data used for visual analysis are the existing road map shapefile and the road map after adding the inspection road plan-interpretation through connectivity space, which shows the movement and space circulation. Spatial connectivity considers the intersection between spaces where the space with the most space contact with other spaces is increasingly connected. An indication of connectivity will be displayed as a colour change.

\subsection{Riverbank Morphology Concept}

River correction, including the construction of embankments, is part of river exploitation [8]. Human activities along the river, be it settlements, road construction, or embankments, are part of river exploitation. It is necessary to carry out ecohydrological engineering to minimize the disruption of river functions, which will focus on the micro-morphology of rivers. Analysis of the river micro-morphology measures the cross-section of the river to determine the parts of riverbanks. They are the floodplain, landslide-prone, ecological buffer, and safety mat[9].

Improvement of river morphology is inseparable from river ecology to maintain water flow and retention against environmental damage[10]. A river is an ecosystem in its channel and boundary consisting of the factors that make up the river ecosystem [11]. Riverbanks have an essential 
function as a buffer between land and river ecosystems.

Analysis of the riverbanks morphology can determine the width of each part and the appropriate treatment for them. The placement of the inspection road and the embankment plan should be adjusted to riverbanks' morphological conditions. Thus, the ecological relationship between rivers and human activities can work well.

\section{Research Location Overview}

\subsection{Physical Descriptions}

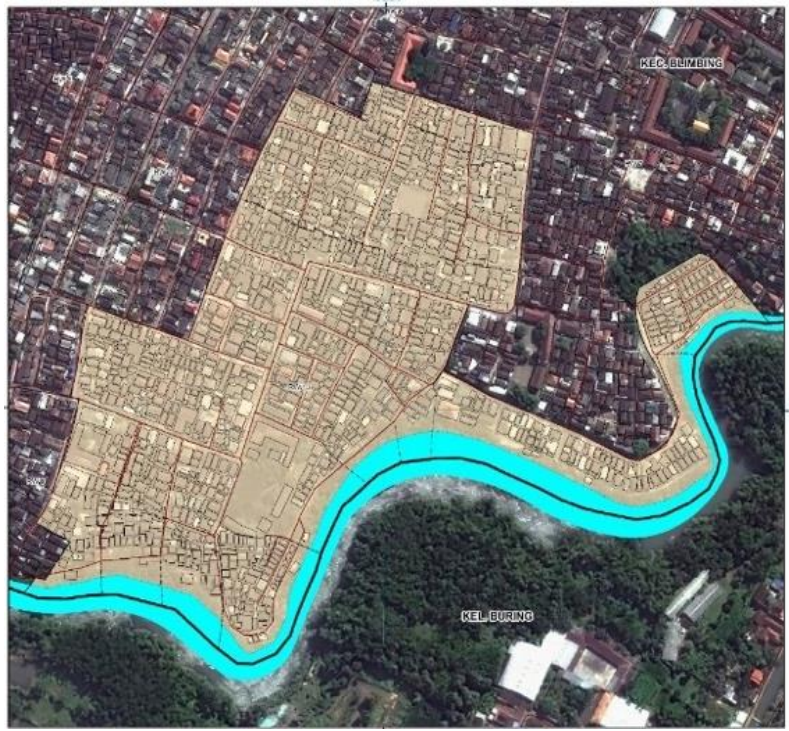

Figure 1. Map of the location. (Source: Processed from Kotalama DED Document)

Figure 1 shows a map of the research location. It shows the density of buildings on the riverbanks of the Amprong River. Based on data obtained from Kotaku in 2019, the following is a physical description of the research location:

\section{1) Building Condition}

The number of buildings is 1,285 units consisting of 1,050 permanent buildings, 141 semi-permanent buildings, and 94 non-permanent buildings. Non-permanent buildings are located along Amprong riverside. The building density is 94.9 units/acre. The distance between the houses is 0.3 meters. The building demarcation line is 0.5 meters.

\section{2) Building Legality}

One thousand one hundred ninety-one building units (92.7\%) have land certificates, while $94(7.3 \%)$ units without the land certificate.

\section{3) Environmental Road}

The length of the road is $719.83 \mathrm{~m}$ with rigid pavement and potholes (see Figure 2).

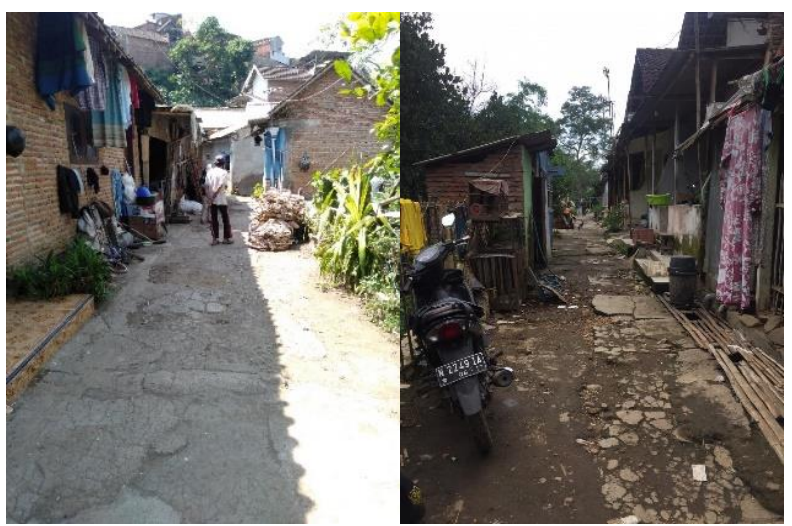

Figure 2. Road Conditions. (Source: Observation, 2020)

4) Wastewater and drinking water supply

Access to toilets and septic tanks are essential aspects of wastewater management. Thirty one houses do not have septic tanks. Their waste disposal is drained and into rivers. As for the availability of three units of Wastewater Treatment Plant, one of which was damaged. The local government drinking water system has served $100 \%$ of the drinking water supply.

\section{5) Drainage}

Based on the existing condition, the drainage channel collects rainwater and blackwater or greywater and waste disposal by the community, which results in clogged drainage and small water flow discharge.

\section{6) Waste Management}

Some houses dispose of their trash at the temporary garbage disposal in the main street. But the garbage cart cannot reach some houses on the riverside, so the residents throw the garbage directly into the river.

\section{7) Fire Protection}

One hydrant near the river can be used as a water source when a fire occurs.

The main reason for some disadvantages experienced in slum settlements on the riverbank is the missing of connected roads. This is a pity because in slums, roads are part of their lives[12], both as public spaces and as connectivity pathways.

\subsection{Social-Cultural Description}

The Madurese tribe dominates the people who live on the Amprong riverbanks, primarily traders. Therefore, they prefer to stay near Pasar Kebalen and Central Market. Those residents are mostly family-related and have been in the area for ages. Some of them were relocated by the government from the banks of the Brantas River. Both Brantas and Amprong riverbanks are highly populated areas in Malang.

The residents' activities of Amprong riverbanks are closely related to the river. They are often bathing, washing, defecating, as well as throwing garbage into the 
river. They also annually commemorate independence days near and on the river, such as flag ceremonies and competitions. Figure 3 shows a photo of a pile of garbage dumped in the riverbank.

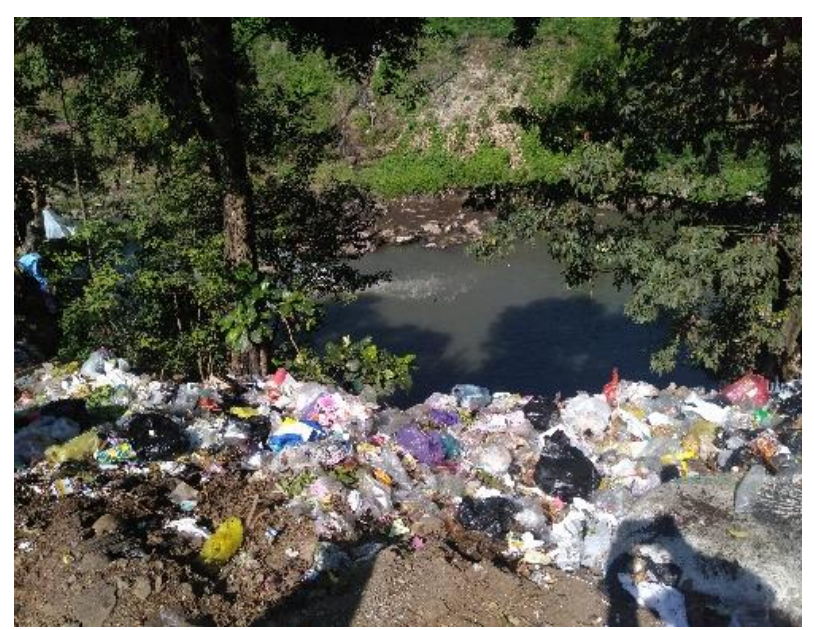

Figure 3. Disposal of garbage directly into the river. (Source: observation results, 2020)

Malang City Government has made efforts to improve the environment quality by constructing public toilets, communal wastewater disposal installations, provision of temporary garbage dumps, and waste transportation networks to almost all areas except the riverbanks. However, some people still prefer to throw their garbage into the river due to a lack of environmental awareness and demanding access to the nearest garbage dump. The garbage cart cannot pass the narrow pathways to the riverbanks' houses with about 1.5 meters in width (see Figure 4).

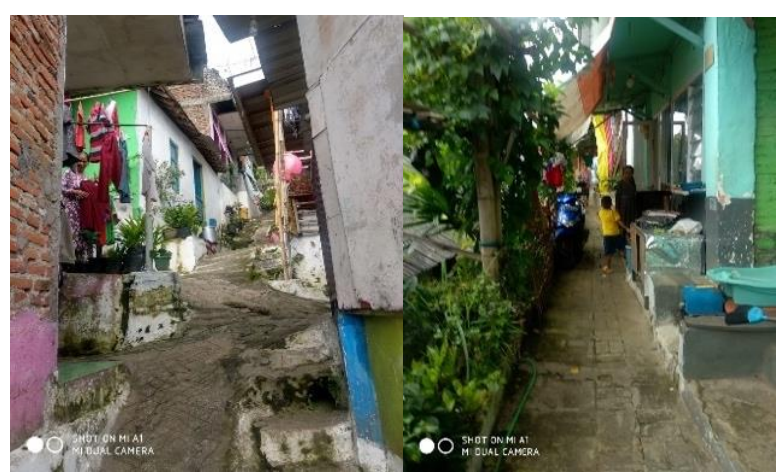

Figure 4. Road in the riverbank settlement. (Source: observation results, 2020)

The disposing of garbage and wastewater can cause high levels of organic waste pollution [13]. Moreover, the Amprong River, as part of the Brantas River Basin, is a source of drinking water in the downstream part, such as in Surabaya. The waste disposal and accessibility problem have led the community members to propose an inspection road that garbage carts can traverse. Also, they proposed the construction of an embankment to prevent landslides.

\section{Result and Discussion}

\subsection{Spatial Morphological Analysis}

The spatial morphological analysis aims to test the accessibility of the proposed inspection road plan. It will be carried out in two stages. The first stage is to do a visual analysis. The second stage is to conduct an axial analysis of the condition of the existing road network and road inspection plans.

\subsubsection{Visual Analysis}

The space configuration uses visual graph analysis to find the centre of an area based on the figure and ground concept. The results can be interpreted by the colour gradation from red, which symbolizes integration or high concentration, to blue, which symbolizes low concentration in an area.

The visual analysis results of the boundary of the planning area and the buildings' configuration can be seen in Figure 5. The highest integration is around elementary schools, which can be interpreted as the centre of the area. Another moderately concentrated area is the riverbank, which includes a park plan and an inspection road plan.

Most of the area on the riverbank is yellow to light blue, indicating moderate integration. This moderate integration is a positive result favouring planning the inspection road, hoping that the construction of this road can become a location for placing public facilities or strategic facilities as a sub-centre of the planning area.

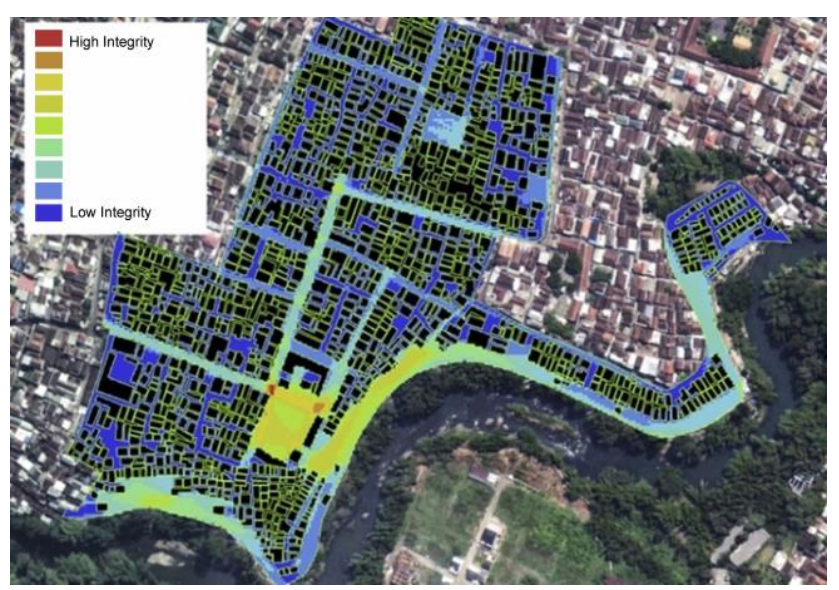

Figure 5. Results of visual analysis. (Source: author's compilation, 2020)

\subsubsection{Axial Analysis}

The spatial configuration is known from the network structure, where the structure is represented by a road network, which is then examined for intersections (nodes) and paths (axial). The network structure is analyzed through axial line analysis, which will produce lines and 
nodes with each connectivity level in a network. The results can be interpreted by the colour gradation, from red, which symbolizes high connectivity, to blue, which symbolizes low connectivity in a network.

The comparison of the axial analysis can be seen in Figure 6. There is a difference in the distribution of road connectivity before and after the inspection road plan. The above picture showing roads with high and moderate connectivity were centred in the middle, namely the path to the elementary school and the existing road on the riverbank. Meanwhile, after the addition of the inspection road plan, it can be seen that there are more roads with moderate connectivity, especially the inspection road that connects the eastern part to the centre of the area. The existence of an inspection road can improve the connectivity of residents on riverbanks.

\subsection{River Morphological Analysis}

The Amprong River is a watershed area of the Brantas River. It plays a vital role in supplying raw materials for drinking water for Surabaya and Malang. The people's habit of throwing garbage and household waste in this river has polluted the river. This habit can trigger natural disasters such as flooding and landslide. The discharge of water during the rainy season causes a high river flow and may cause flooding. Heavy rain could increase the volume of water up to one meter from the riverbank. Landslides commonly occur because of the slope of the land reaching $>30^{\circ}$. Areas with the potential of landslide incidents can be seen in Figure 7.

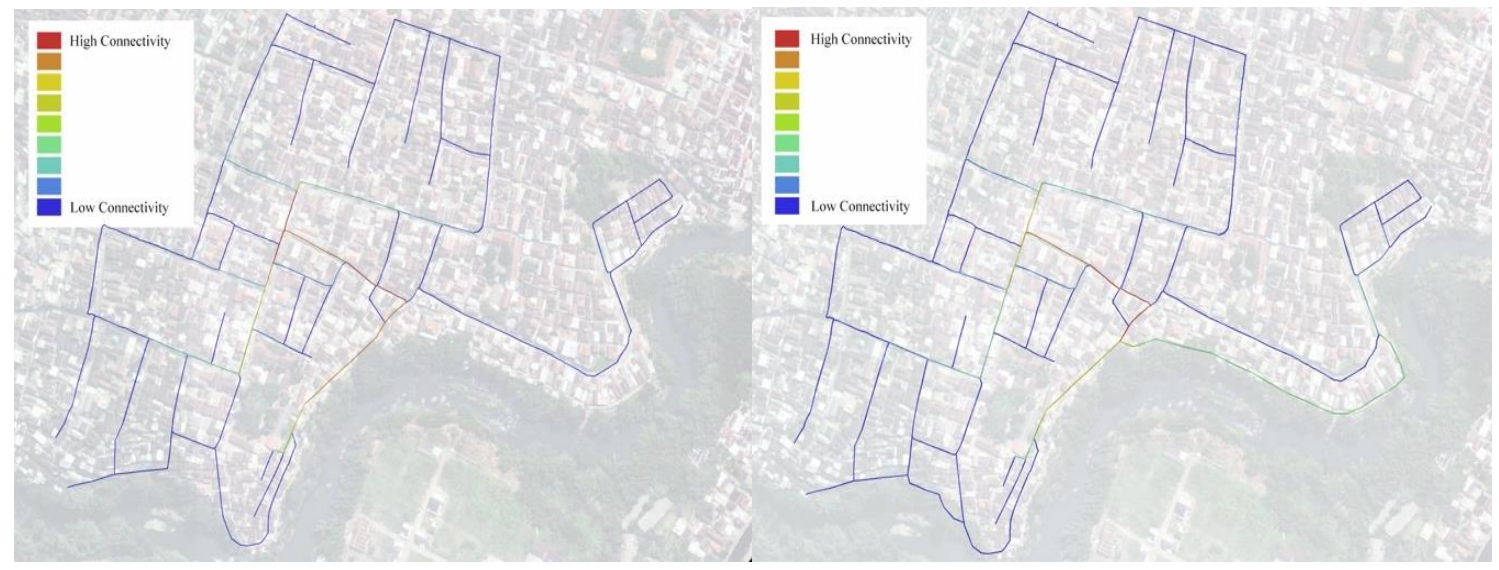

Figure 6. Comparison of axial analysis results. Above: existing road network. Below: planned inspection road (Source: prepared by the author, 2020)

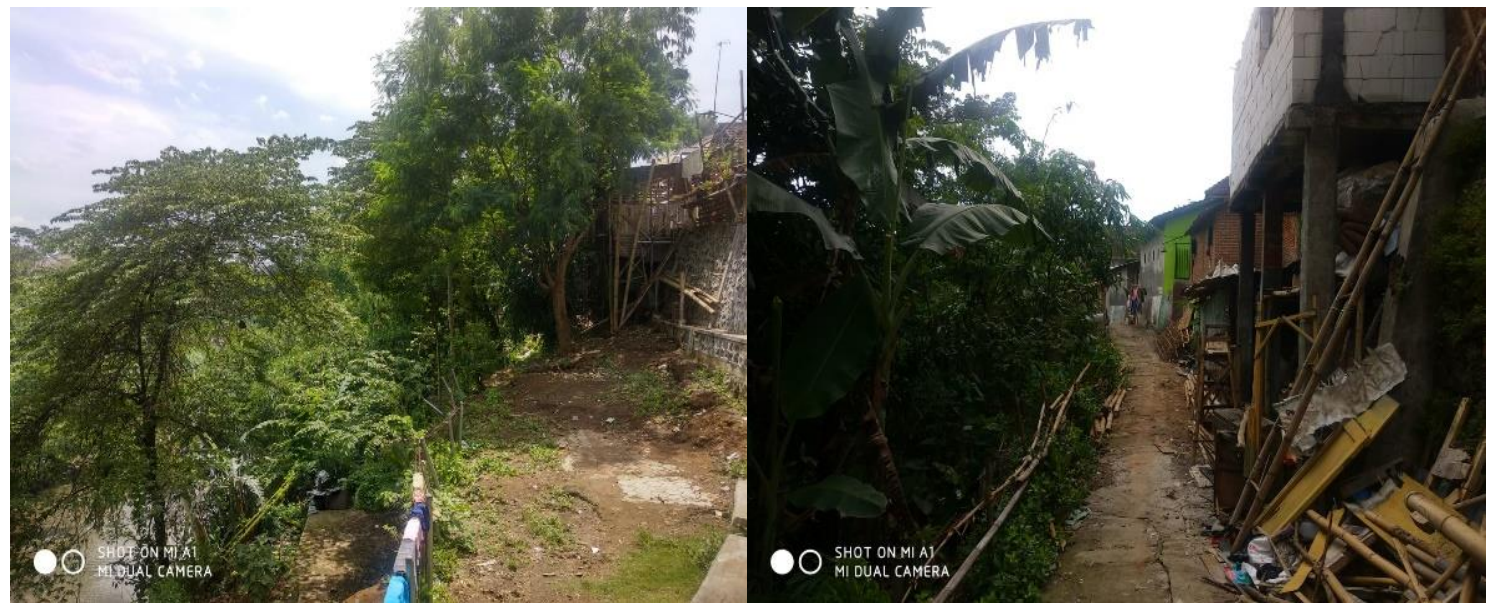

Figure 7. River border area with land slope $>30^{\circ}$ (above) and settlement conditions on the riverbank (below). (Source: observation results, 2020) 


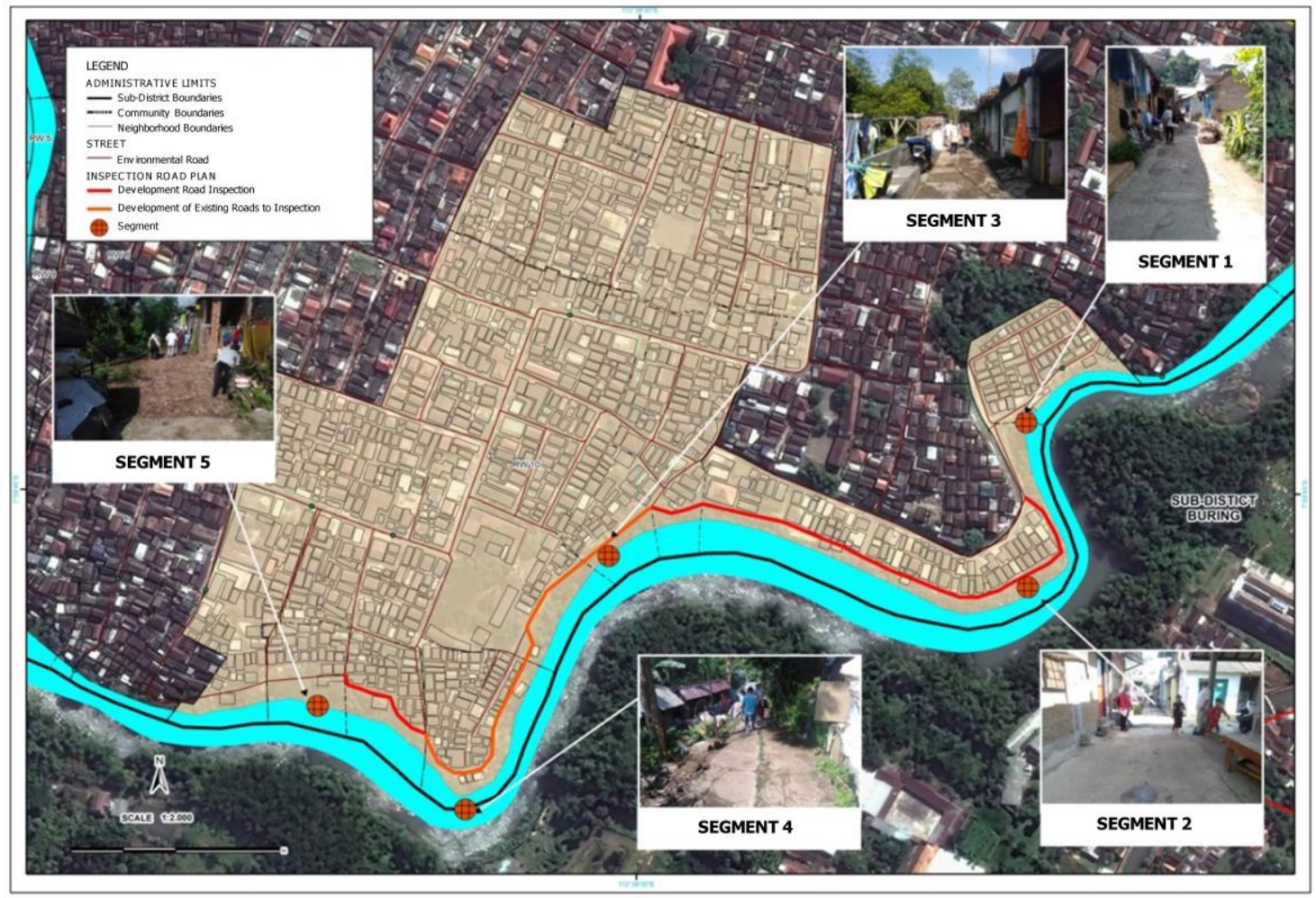

Figure 8. Location of the cross section of the river border. (Source: Kotalama DED document, 2020)

To overcome the slum environment condition, the construction of an inspection road and an 886-meter long embankment are planned on the river bank. Segment determination and measurement images were obtained from the 2020 Kotalama DED Document (see Figure 8). The cross-section data, then analyzed by dividing the physical morphology across the river boundaries from each segment.

Riverbank division aims to determine safety and sustainable design engineering. It prevents landslides in accommodating settlements and inspection roads, retaining floods, and maintaining rivers' ecological function. In segment 1 and 5, the riverbanks are divided into the floodplain, landslide-prone, and ecological buffer; the floodplain and ecological buffer for segment 2; floodplain and landslide-prone for segment 3 and 4 . Settlements in segments 1,2 , and 5 are on the safety mat, while those in 3 and 4 are on the landslide-prone.

The construction of the embankment will change the cross-sectional shape of the river. Based on the cross-sectional analysis, the embankment's construction is expected to eliminate the landslide boundary area and replace it with an ecological boundary. Thus, the construction of the inspection road can be applied to the safety mat.

Implementing permanent embankment is not the only approach to dealing with erosion and sedimentation problems on riverbanks. Figure 9 depicts a concept comparison between the non-eco-hydraulic and eco-hydraulic embankments. The eco-hydraulics structure can be developed from reprofiled and revegetated banks with rock toe reinforcement [14]. It is applied according to the following procedure. Firstly, sloping the cliffs to a slope of $\left\langle 30^{\circ}\right.$; secondly, making a permanent embankment in the terracing system and putting river stones between terraces; lastly, planting grass, herbs, shrubs, and trees. For floodplains, the slopes are rammed and installed with river stones and grass or other vetiver plants.

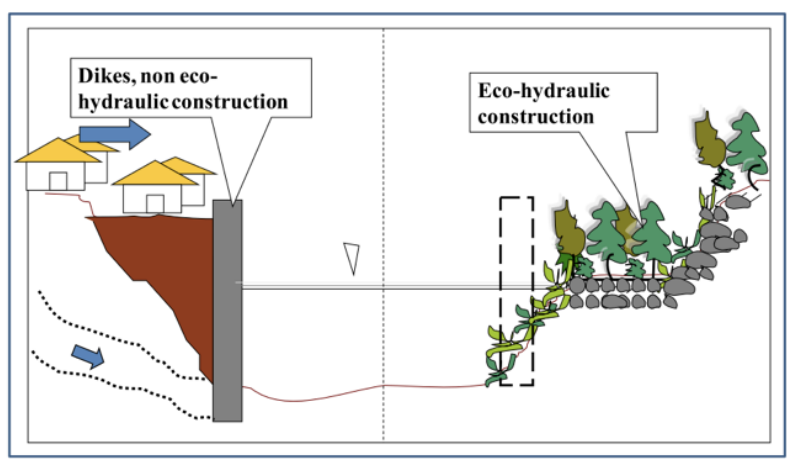

Figure 9. Comparison between the embankment of non eco-hydraulic and eco-hydraulic. (Source: Banten Province Environmental Service, 2019)

Figures 10 - 14 show the cross-section analysis of each segment. The figure above shows the river boundaries' distribution, while the figure below shows the proposed placement of embankments and inspection roads. In segments 1,2, and 5, settlements and inspection roads can be placed on the safety mat. In segments 3 and 4 , permanent embankments need to be built on the left side of the settlement, while the inspection road is located as part of the ecological buffer. 

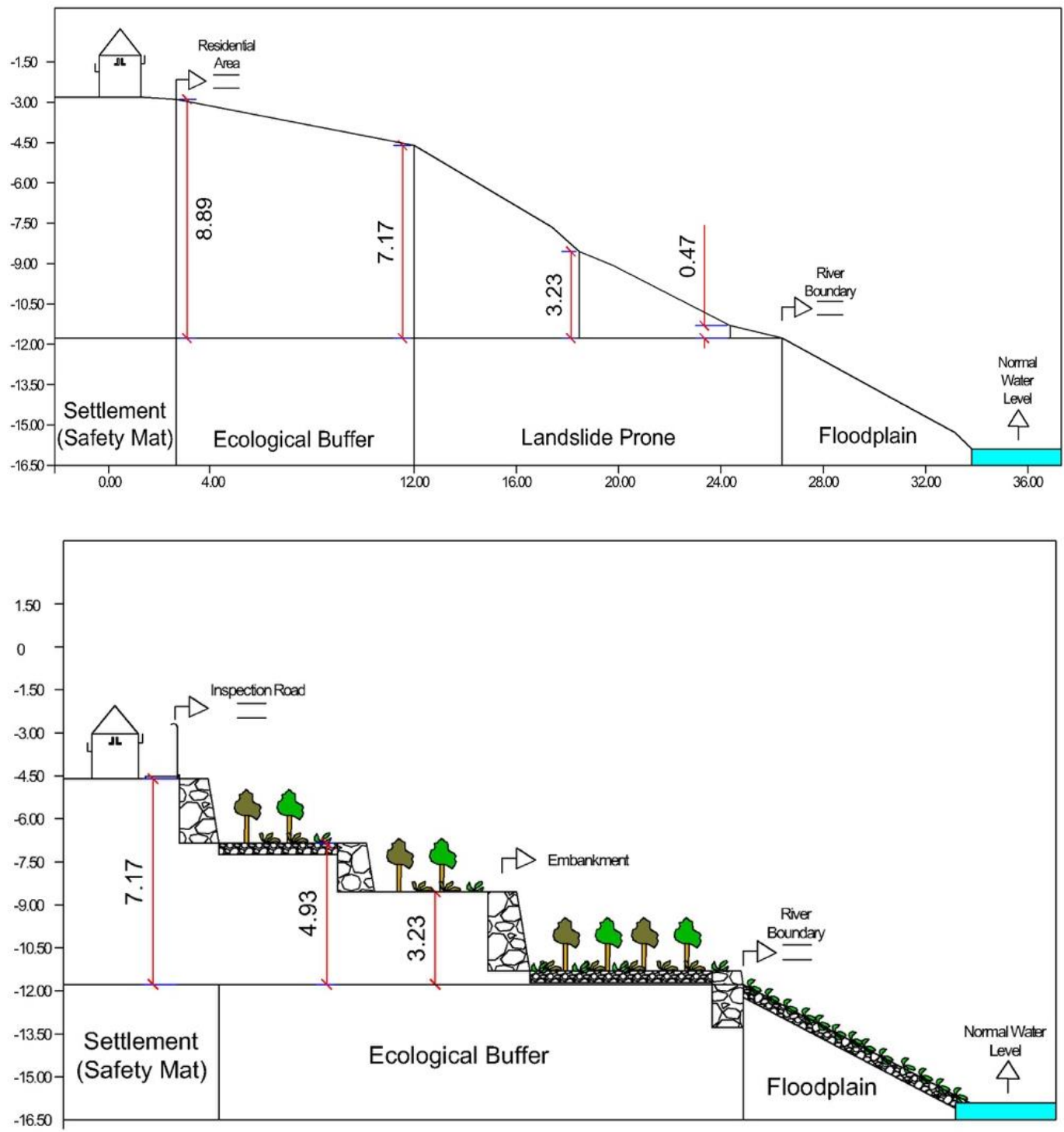

Figure 10. Segment 1: River border division (top) and directions for placement of embankments and inspection roads (bottom). (Source: author's compilation, 2020) 

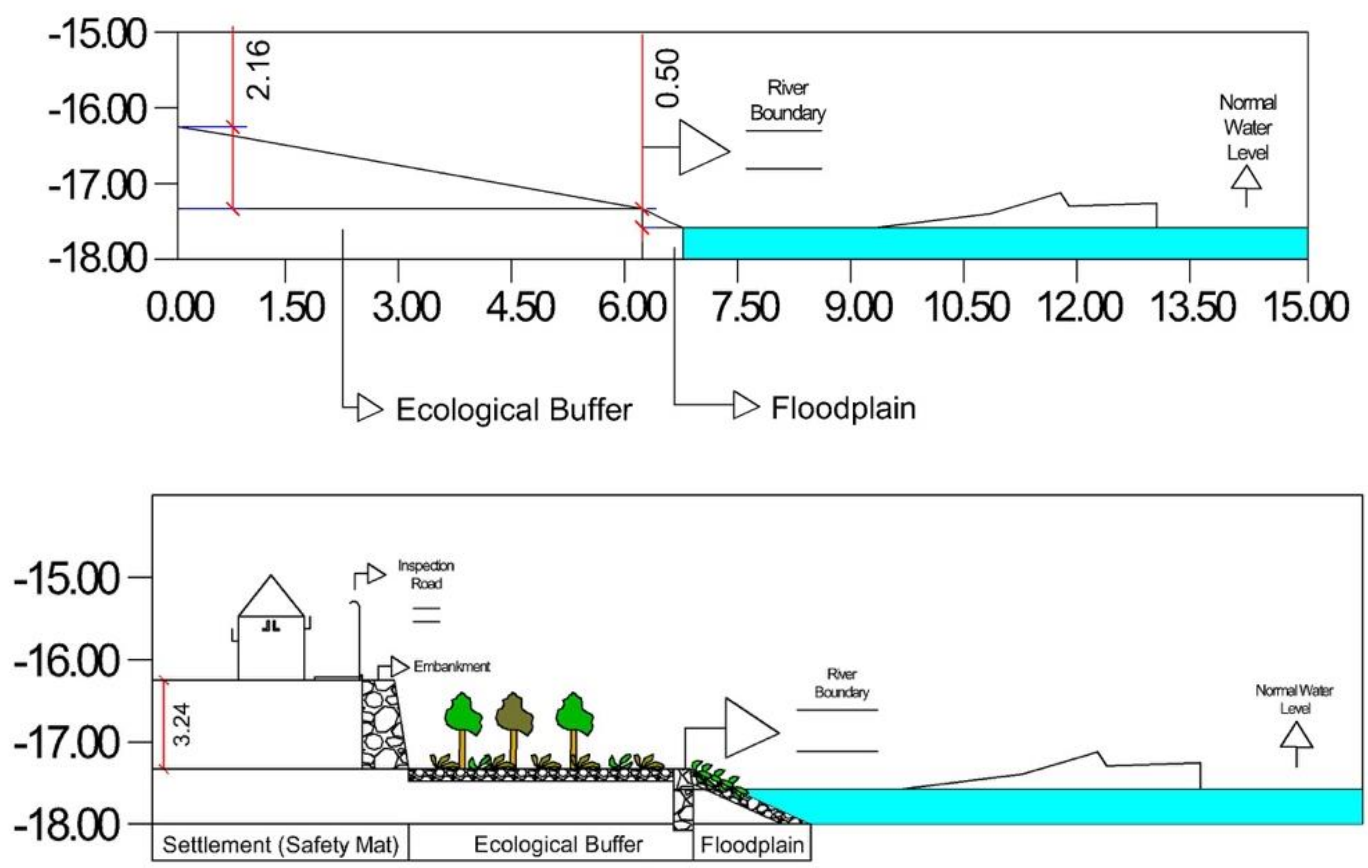

Figure 11. Segment 2: River border division (top) and directions for placement of embankments and inspection roads (bottom). (Source: author's compilation, 2020)
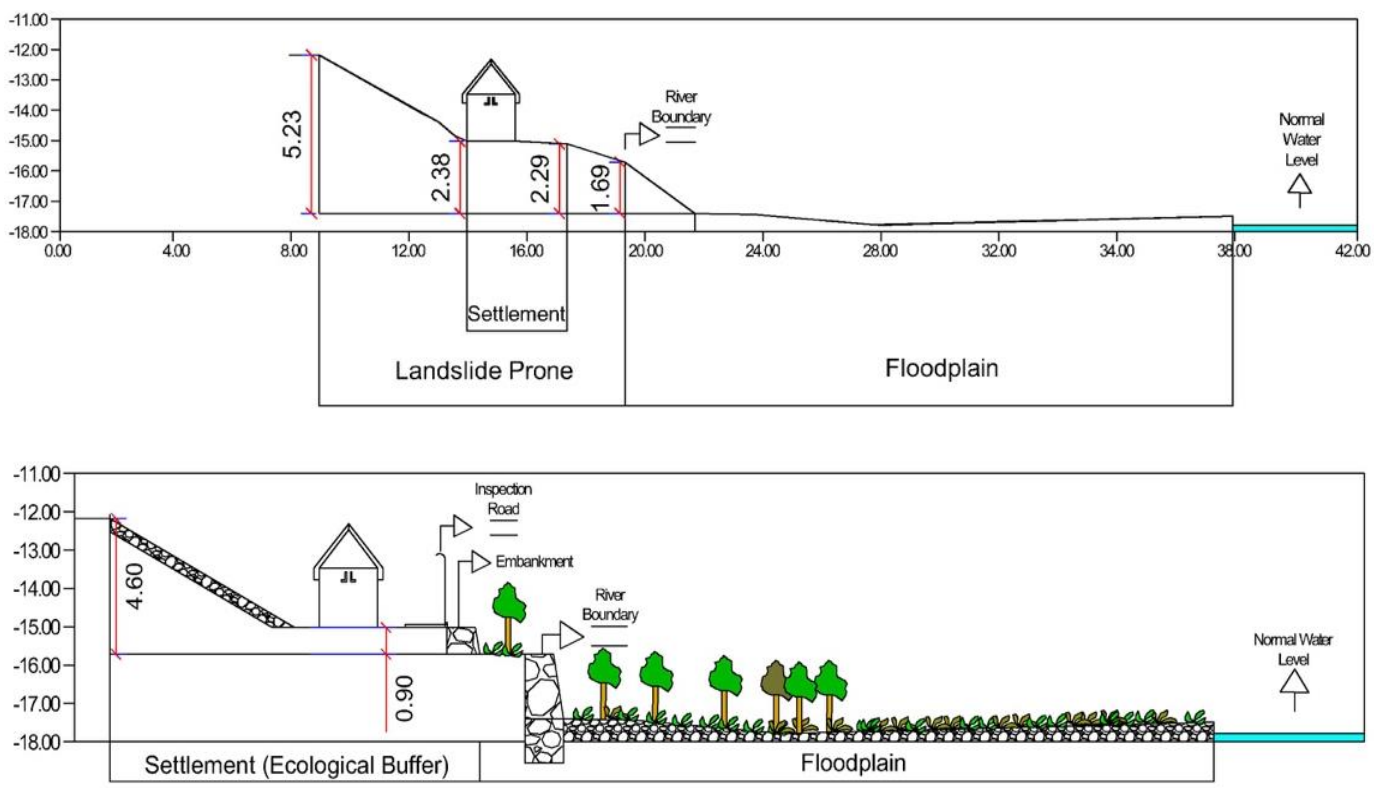

Figure 12. Segment 3: River boundary division (top) and directions for placement of embankments and inspection roads (bottom). (Source: author's compilation, 2020) 

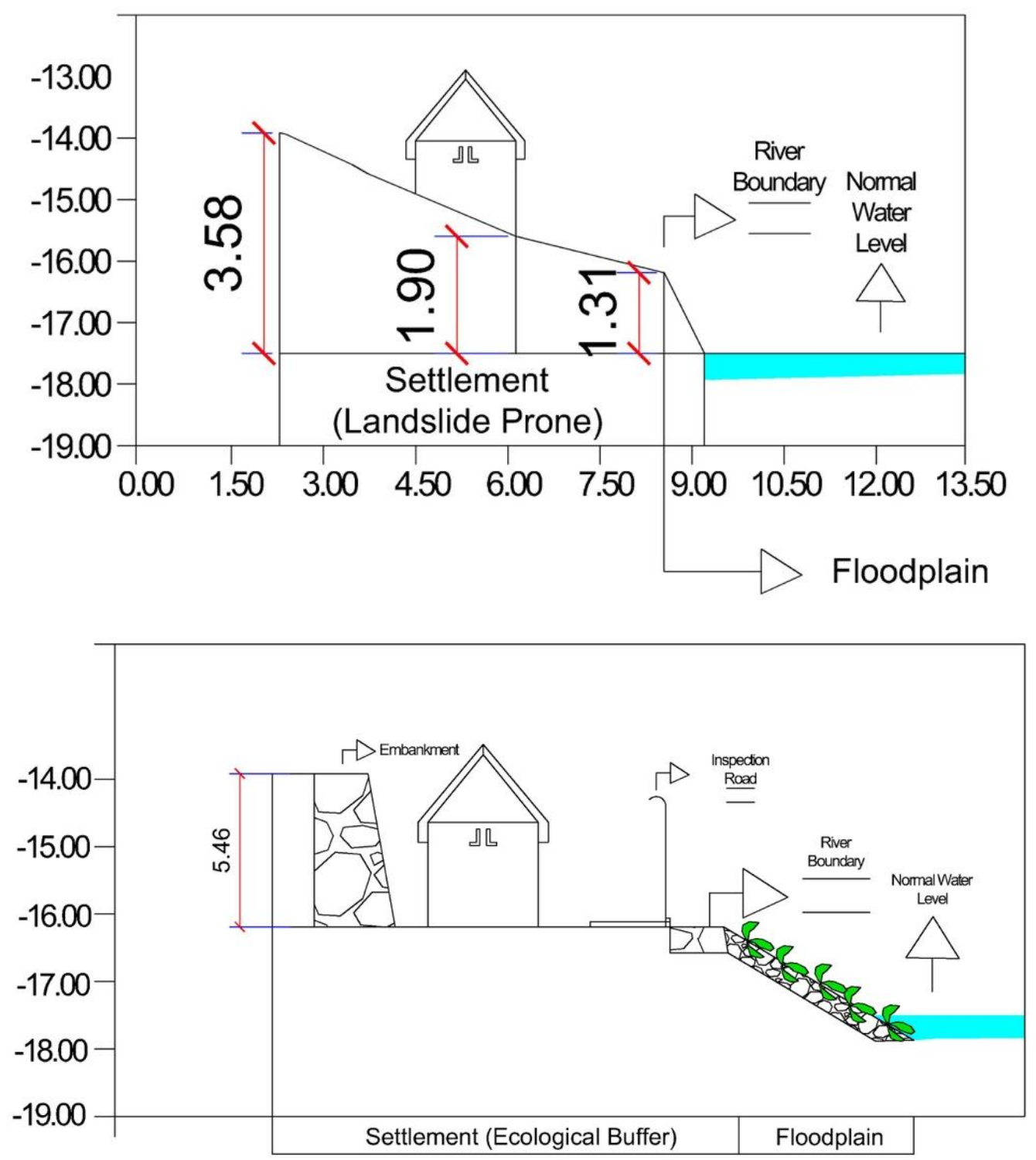

Figure 13. Segment 4: River boundary division (top) and directions for placement of embankments and inspection roads (bottom). (Source: author's compilation, 2020) 

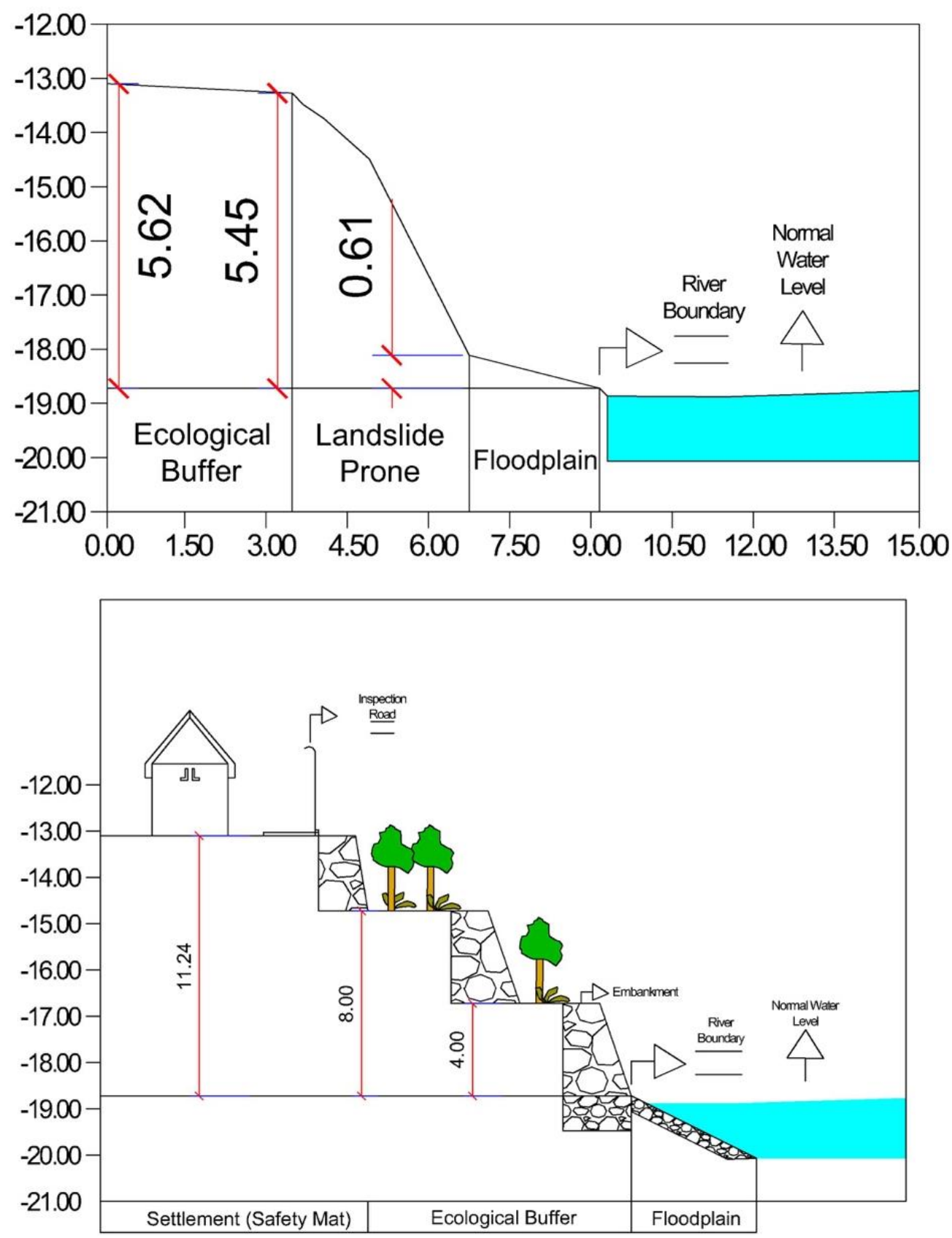

Figure 14. Segment 5: River border division (left) and directions for placement of embankments and inspection roads (right). (Source: author's compilation, 2020)

The embankments built on the landslide banks are devoted to strengthening the soil structure, while the one on the floodplain is specifically designed to prevent river erosion. Meanwhile, the river ecology is directed to install landslide resistant plants such as vetiver grass, elephant grass, and king grass. These plants functions to control erosion[15].

The planning of the inspection road follows the planning of the embankment. Based on the results of interviews with local communities, the construction of embankments and inspection roads are among the infrastructure needed by the community. Construction of the inspection road will be planned along the river with a width of 2.5 meters, a green lane of 0.5 meters and a safety fence. The road corridor can be an active open space, and the green lane can be a passive one[16].The safety fence is used for road safety and to prevent direct dumping of garbage into the river. The fence should be made of light material to create an open space and avoid blocking the view toward the river. The inspection road design for all segments is typical (see Figure 15). 


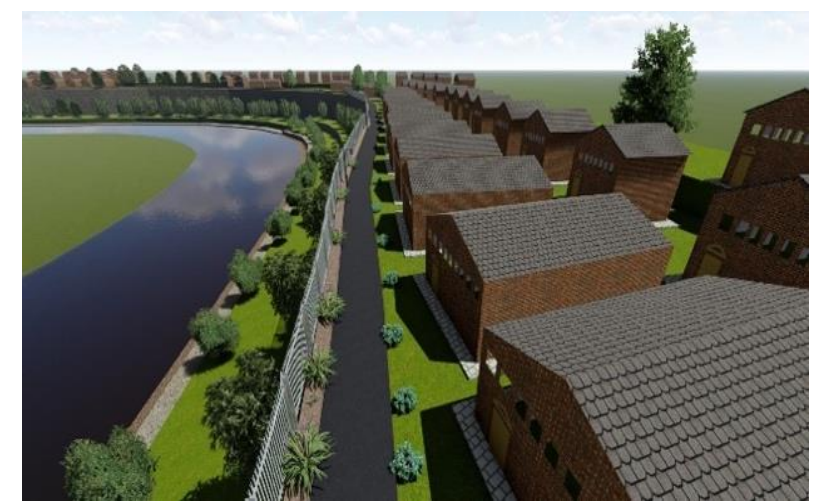

Figure 15. Design of the Inspection Road Plan. (Source: author's compilation, 2020)

\section{Conclusions}

Part of the Kotalama slum area, especially settlements on the riverbanks, suffers the most regarding low connection and landslide thread. The improper habits of people (throwing garbage and waste directly into the river) rise water pollution. An inspection road construction program and a landslide prevention embankment are planned to improve the environment quality.

The first stage of spatial morphological analysis, namely visual analysis, shows that the centre of the research area is around the elementary school. The part where the planned inspection road is located shows moderate spatial integration leading to potency to become a sub-centre for the area. Public facilities can be located along the inspection route. Positive results were also shown in the second stage (axial analysis). The construction of the inspection road increases the equal distribution of connectivity.

Next, the river boundary morphological analysis revealed two segments where residential buildings are located on the landslide banks from the cross-section of the five segments. The Amprong River cliffs' characteristics also tend to be steep, with a slope of more than $30^{\circ}$. This condition requires the need for terraced embankments for double protection against landslides and erosion. Meanwhile, the inspection road design is typical and wide enough for a motorcycle, and a garbage cart also added with a safety fence.

\section{REFERENCES}

[1] Khomarudin. Tracing Housing and Settlement Development. Jakarta: PT. Rakasindo, 1997.

[2] Regulation of the Minister of Public Works and Spatial Planning No. 14 of 2018 concerning Prevention and Improvement of the Quality of Housing and Slum
Settlements. State Gazette of the Republic of Indonesia. Jakarta: State Secretariat.

[3] Mau, W. A. T. Study of Slum Settlements in Riverbank Areas based on Legality Aspects in the Village of Oro-oro Dowo, Malang City. 1(1), 1-21, 2016.

[4] Hillier, B., \& Hanson, J. The analysis of settlement layouts. In The Social Logic of Space (pp. 82-142). Cambridge University Press, 1984. https://doi.org/10.1017/CBO978051 1597237.005

[5] Romdhoni, M. F. Analysis of Urban Open Space Configuration Patterns Using the Space Syntax Method as Spatial Logic and Space Use. NALARs, 17(2), 113, 2018. https://doi.org/10.24853/nalars.17.2.113-128

[6] Turner, A., Doxa, M., O’Sullivan, D., \& Penn, A. From isovists to visibility graphs: A methodology for the analysis of architectural space. Environment and Planning B: Planning and Design, 28(1), 103-121, 2001. https://doi.org/ $10.1068 / \mathrm{b} 2684$

[7] depthmapX development team. depthmapX (Version 0.6.0) [Computer software]. 2017. Retrieved from https://github.co $\mathrm{m} /$ SpaceGroupUCL/depthmapX/

[8] Banten Province Environmental Service. Watershed Management Policy (Water Conservation) As A Paradigm Change in Environmentally Friendly River Management, 2019. https://dlhk.bantenprov.go.id/read/article/729/Keb Policy-Peng

Manajemen-DAS-Konservasi-Air-Sebagai-Perubah-Paradig ma-Dalam-Peng Manajemen-S Sungai-Yang-Ramah-Lingk ungan.html

[9] Maryono, A. A Study Of Stream buffer Width (Case Study of Rivers in Daerah Istimewa Yogyakarta Province). Dinamika TEKNIK SIPIL, vol 9 nomo(Januari), 55-66, 2009.

[10] Suryanta, J., Nursugi, \& Nahib, I. Identification of River Morphology with Satellite Image of River Restoration (Case Study of Upper Solo). Prosiding Seminar Nasional Geografi UMS IX 2018, 1(1), 449-457, 2018.

[11] Sujono, I. Water Restoration of Brantas River. Osf, Surabaya, 2019. https://osf.io/dzk7x/

[12] Hatipoglu, H. K., \& Mahmut, S. B. Borders (In between): A city within a city decoding different morphologies of fragmented housing. Civil Engineering and Architecture, 8(5), 880-889, 2020. https://doi.org/10.13189/cea.2020.080 515

[13] Yetti, E., Soedharma, D., Sigid, D., Haryadi. Evaluation of River Water Quality in the Upper Brantas Watershed Area of Malang. Tesis. Bogor: Institut Pertanian Bogor, 2011.

[14] Rini, D. S. Application of Ecohydraulics Engineering to Strengthen River Cliffs and Restore Habitat of the Kali Surabaya Fish Sanctuary. Seminar Nasional Sains Dan Teknologi Terapan III 2015, 763-773, 2015. http://jurnal.ita ts.ac.id/wp-content/uploads/2015/10/20.-Daru_Itats.pdf

[15] Siregar, BR Friska. Effectiveness of Vetiver Grass (Vetiveria zizaniodies L), Elephant Grass (Pennisetum purpureum), and King Grass (Pennisetum tydoides) in Controlling Erosion in Ultisols. Skripsi. Padang: Universitas Andalas, 2019. 
[16] Sushanti, I. R., Abednego, I. A., Septanti, D., Santosa, H. R., \& Kisnarini, R. Waterfront concept development with community-based tourism. IOP Conference Series: Earth and
Environmental Science, 447(1), https://doi.org/10.1088/1755-1315/447/1/012019
2020. 